\title{
ORTHOGONAL CONTRASTS: DEFINITIONS AND CONCEPTS
}

\author{
Maria Cristina Stolf Nogueira \\ USP/ESALQ - Depto. de Ciências Exatas, C.P. 9 - 13418-900 - Piracicaba, SP - Brasil. \\ e-mail <mcsnogue@esalq.usp.br>
}

\begin{abstract}
The single degree of freedom of orthogonal contrasts is a useful technique for the analysis of experimental data and helpful in obtaining estimates of main, nested and interaction effects, for mean comparisons between groups of data and in obtaining specific residuals. Furthermore, the application of orthogonal contrasts is an alternative way of doing statistical analysis on data from non-conventional experiments, whithout a definite structure. To justify its application, an extensive review is made on the definitions and concepts involving contrasts.
\end{abstract}

Key words: analysis of variance, partition of sum of squares, experiments with additional treatments

\section{CONTRASTES ORTOGONAIS: DEFINIÇÕES E CONCEITOS}

\begin{abstract}
RESUMO: A técnica de contrastes ortogonais com um grau de liberdade é simples e bastante eficiente na análise de dados experimentais, como por exemplo, na obtenção de efeitos principais, de efeito de interação e de efeitos aninhados, nas comparações entre grupos de médias e na obtenção dos resíduos específicos. Além disso, sua aplicação tem revelado ser uma forma alternativa para análise de dados obtidos de um experimento que não segue uma estrutura definida. Com o objetivo de justificar a sua aplicação, foi realizada uma revisão sobre as definições e os conceitos envolvendo contrastes.

Palavras-chave: análise da variância, partição da soma de quadrados, experimentos com tratamentos adicionais
\end{abstract}

\section{INTRODUCTION}

The orthogonal contrast technique is a simple and efficient way of analysing experimental data to obtain, for instance, the main effects, interaction effects and nested effects, for comparisons between groups of means and/ or to obtain specific residuals. Additionally, the application of orthogonal contrasts is an alternative way of doing statistical analysis on data from experiments without a definite structure, like the experiments with additional treatments. The objective of this paper review was to justify the application of the single degree of freedom orthogonal contrasts in the analysis of experimental data from non-conventional experiments, recently published by Nogueira \& Corrente (2000) and Corrente et al. (2001).

\section{Definitions and concepts for mean contrasts with equal number of replications}

Scheffé (1959), Winer (1971), Steel \& Torrie (1981), Mead (1988) and Hinkelmann \& Kempthorne (1994), among others, define a contrast between treatment means, represented by $\mathrm{Y}$, as a linear function that can be estimated, considering an equal number of replications for all treatments, as follows:

$$
\mathrm{Y}=\sum_{\mathrm{i}=1}^{\mathrm{I}} \mathrm{c}_{\mathrm{i}} \mu_{\mathrm{i}}
$$

where $c_{i}$ are values of coefficients associated to $\mu_{i}$, and $\mu_{\mathrm{i}}$ the mean attributed to the treatment $i$, so that

$$
\sum_{\mathrm{i}=1}^{\mathrm{I}} \mathrm{c}_{\mathrm{i}}=0 \text {. }
$$

Supposing the mathematical model $\mathrm{Y}_{\mathrm{ij}}=\mu+\mathrm{t}_{\mathrm{i}}+\mathrm{e}_{\mathrm{ij}}$, when $\mathrm{i}=1, \ldots, \mathrm{I}$ and $\mathrm{j}=1, \ldots, \mathrm{r}$, and $\mu$ being a constant, $t_{i}$ the treatment effect $i$, so that: $\sum_{i=1}^{I} t_{i}=0$, and $e_{i j}$ the experimental error, so that $\mathrm{e}_{\mathrm{ij}} \sim \mathrm{N}\left(0, \sigma^{2}\right)$ and independent of each other.

Supposing that $\mu_{\mathrm{i}}=\mu+\mathrm{t}_{\mathrm{i}}$, then

$$
\mathrm{Y}=\sum_{\mathrm{i}=1}^{\mathrm{I}} \mathrm{c}_{\mathrm{i}}\left(\mu+\mathrm{t}_{\mathrm{i}}\right)=\mu \sum_{\mathrm{i}=1}^{\mathrm{I}} \mathrm{c}_{\mathrm{i}}+\sum_{\mathrm{i}=1}^{\mathrm{I}} \mathrm{c}_{\mathrm{i}} \mathrm{t}_{\mathrm{i}}=\sum_{\mathrm{i}=1}^{\mathrm{I}} \mathrm{c}_{\mathrm{i}} \mathrm{t}_{\mathrm{i}}
$$

Two contrasts $Y_{h}=\sum_{i=1}^{I} c_{h i} \mu_{\mathrm{i}}$ and $Y_{h^{\prime}}=\sum_{\mathrm{i}=1}^{\mathrm{I}} \mathrm{c}_{\mathrm{h}^{\prime} \mathrm{i}} \mu_{\mathrm{i}}$, since $h \neq h^{\prime}$ and $h=1, \ldots$, (I-1), are orthogonal, if $\operatorname{Cov}\left(\mathrm{Y}_{\mathrm{h}}, \mathrm{Y}_{\mathrm{h}}\right)=0$. Thus, for the adopted model $\operatorname{Cov}\left(\mathrm{Y}_{\mathrm{h}}, \mathrm{Y}_{\mathrm{h}^{\prime}}\right)=\frac{\sigma^{2}}{\mathrm{r}} \sum_{\mathrm{i}=1}^{\mathrm{I}} \mathrm{c}_{\mathrm{hi}} \mathrm{c}_{\mathrm{h}^{\mathrm{i}}}$, occurs when $\left\langle\mathrm{c}_{\mathrm{hi}}, \mathrm{c}_{\mathrm{h}^{\prime} \mathrm{i}}\right\rangle=0$, that is $\sum_{\mathrm{i}=1}^{\mathrm{I}} \mathrm{c}_{\mathrm{hi}} \mathrm{c}_{\mathrm{h}^{\prime} \mathrm{i}}=0$.

Supposing $\hat{\mathrm{Y}}_{\mathrm{h}}$ is an estimator in such way that 
$\hat{\mathrm{Y}}_{\mathrm{h}}=\sum_{\mathrm{i}=1}^{\mathrm{I}} \mathrm{c}_{\mathrm{hi}} \overline{\mathrm{y}}_{\mathrm{i} .}$, with $\overline{\mathrm{y}}_{\mathrm{i} .}=\frac{\sum_{\mathrm{j}=1}^{\mathrm{r}} \mathrm{y}_{\mathrm{ij}}}{\mathrm{r}}$,

considering $e_{i j} \sim N\left(0, \sigma^{2}\right)$ and independent of each other, then $\hat{Y}_{h}$ is an unbiased estimator for $Y_{h}$ and

$$
\mathrm{V}\left(\hat{\mathrm{Y}}_{\mathrm{h}}\right)=\sum_{\mathrm{i}=1}^{\mathrm{I}} \mathrm{c}_{\mathrm{hi}}^{2} \mathrm{~V}\left(\overline{\mathrm{y}}_{\mathrm{i} .}\right)=\sum_{\mathrm{i}=1}^{\mathrm{I}} \mathrm{c}_{\mathrm{hi}}^{2} \frac{\sigma^{2}}{\mathrm{r}}=\sum_{\mathrm{i}=1}^{\mathrm{I}} \frac{\mathrm{c}_{\mathrm{hi}}^{2}}{\mathrm{r}} \sigma^{2} .
$$

A special characteristic of orthogonal contrasts is that they may easily be included in the analysis of variance, in such way that they originate sums of squares with one degree of freedom which correspond, each of them, to the (I-1) subdivisions of the sum of squares due to the treatments with (I-1) degrees of freedom. That is, the sum of squares due to the treatments can be decomposed in (I-1) sums of squares due to the contrasts with one degree of freedom.

Mead (1988) demonstrated this characteristic of the orthogonal contrasts and defined that the sum of squares due to $\mathrm{Y}_{\mathrm{h}}$ is given by:

$\operatorname{SSY}_{\mathrm{h}}=\frac{\mathrm{r}\left[\sum_{\mathrm{i}=1}^{\mathrm{I}} \mathrm{c}_{\mathrm{hi}} \overline{\mathrm{y}}_{\mathrm{i} .}\right]^{2}}{\sum_{\mathrm{i}=1}^{\mathrm{I}} \mathrm{c}_{\mathrm{hi}}^{2}}=\frac{\mathrm{r} \hat{\mathrm{Y}}_{\mathrm{h}}^{2}}{\sum_{\mathrm{i}=1}^{\mathrm{I}} \mathrm{c}_{\mathrm{hi}}^{2}}$ with one degree of freedom

and consequently, the sum of squares due to treatments is given by:

$\mathrm{SST}=\sum_{\mathrm{h}=1}^{\mathrm{I}-1} \mathrm{SSY}_{\mathrm{h}}$ with (I-1) degrees of freedom.

Hence, supposing $Y_{h}=\sum_{i=1}^{I} c_{h i} t_{i}$ is a contrast of treatment effects, so that

$\sum_{\mathrm{i}=1}^{\mathrm{I}} \mathrm{c}_{\mathrm{hi}}=0$ and $\sum_{\mathrm{i}=1}^{\mathrm{I}} \mathrm{c}_{\mathrm{hi}} \mathrm{c}_{\mathrm{h}^{\prime} \mathrm{i}}=0$, with $\mathrm{h} \neq \mathrm{h}$, for $\mathrm{h}=1, \ldots$,

(I-1), and $\mathrm{g}_{\mathrm{hi}}$ is a coefficient defined as:

$$
\mathrm{g}_{\mathrm{hi}}=\frac{\mathrm{c}_{\mathrm{hi}}}{\sqrt{\sum_{\mathrm{i}=1}^{\mathrm{I}} \mathrm{c}_{\mathrm{hi}}^{2}}},
$$

so that $\sum_{\mathrm{i}=1}^{\mathrm{I}} \mathrm{g}_{\mathrm{hi}}=0, \sum_{\mathrm{i}=1}^{\mathrm{I}} \mathrm{g}_{\mathrm{hi}} \mathrm{g}_{\mathrm{h}^{\prime} \mathrm{i}}=0$, with $\mathrm{h} \neq \mathrm{h}^{\prime}, \mathrm{h}=1$, $\ldots$, (I-1) and $\sum_{\mathrm{i}=1}^{\mathrm{I}} \mathrm{g}_{\mathrm{hi}}^{2}=1$, originating orthonormal contrasts. Consider also a group of (I-1) orthogonal linear functions of the treatment effects expressed in the follow- ing matrix form:

$$
\mathrm{z}=\left(\begin{array}{l}
\mathrm{g}_{1}^{\prime} \\
\mathrm{g}_{2}^{\prime} \\
\vdots \\
\mathrm{g}_{\mathrm{I}-1}^{\prime}
\end{array}\right) \hat{\tau}=\mathrm{G}^{\prime} \hat{\tau}
$$

where $\mathrm{g}_{\mathrm{h}}^{\prime}=\left(\mathrm{g}_{\mathrm{h} 1}, \mathrm{~g}_{\mathrm{h} 2}, \ldots, \mathrm{g}_{\mathrm{hI}}\right)$, for $\mathrm{h}=1, \ldots$, $(\mathrm{I}-1) ; \tau^{\prime}=\left(\mathrm{t}_{1}, \mathrm{t}_{2}, \ldots, \mathrm{t}_{\mathrm{I}}\right)$ is the vector of the estimates of the treatment effects. Thus, the vector $\mathrm{z}$ will be a group of (I-1) estimates of the considered orthogonal contrasts, and that, due to the contrast orthogonality, the contrast estimates are independent, that is, the $\mathrm{z}_{\mathrm{h}}$ are independent of each other. Thus, $\mathrm{z}_{\mathrm{h}}=\mathrm{g}_{\mathrm{h}}^{\prime} \hat{\tau}$, for $\mathrm{h}=1,2, \ldots,(\mathrm{I}-1)$. If the variable observations follow a normal distribution, then the vector $\mathrm{z}$ is a normal aleatory variable vector and independently distributed, and each element has mean = zero and variance $=1$.

Adding to the matrix G' a line vector $\mathrm{g}_{0}$, so that $\mathrm{g}_{0}^{\prime}=\frac{1}{\sqrt{\mathrm{I}}} \mathrm{E}^{\prime}$, where $\mathrm{E}$ is a vector of 1 's, the data matrix will take the form:

$$
\mathrm{z}^{*}=\left(\begin{array}{l}
\mathrm{g}_{0}^{\prime} \\
\mathrm{g}_{1}^{\prime} \\
\vdots \\
\mathrm{g}_{\mathrm{I}-1}^{\prime}
\end{array}\right) \hat{\tau}=\left(\begin{array}{l}
\mathrm{g}_{0}^{\prime} \\
\mathrm{G}^{\prime}
\end{array}\right) \hat{\tau}=\mathrm{G}^{*} \hat{\tau},
$$

where the data matrix $\mathrm{G}^{*}$ ' is an orthogonal matrix, having $G^{*} G^{*}=I$, and for this reason $G^{*}=\left(G^{* \prime}\right)^{-1}$, resulting $\mathrm{G}^{*} \mathrm{G}^{*}=\mathrm{I}$.

\section{Supposing}

$$
\mathrm{z}_{\mathrm{h}}^{2}=\left[\mathrm{g}_{\mathrm{h}}^{\prime} \hat{\tau}\right]^{2}=\left[\sum_{\mathrm{i}=1}^{\mathrm{I}} \mathrm{g}_{\mathrm{hi}} \hat{\mathrm{t}}_{\mathrm{i}}\right]^{2}=\left[\sum_{\mathrm{i}=1}^{\mathrm{I}} \mathrm{g}_{\mathrm{hi}} \overline{\mathrm{y}}_{\mathrm{i} .}\right]^{2}
$$

where $\mathrm{g}_{\mathrm{hi}}=\frac{\mathrm{c}_{\mathrm{hi}}}{\sqrt{\sum_{\mathrm{i}=1}^{\mathrm{I}} \mathrm{c}_{\mathrm{hi}}^{2}}}$, for $\mathrm{h}=1, \ldots,(\mathrm{I}-1)$, thus

$\mathrm{z}_{\mathrm{h}}^{2}=\frac{\left[\sum_{\mathrm{i}=1}^{\mathrm{I}} \mathrm{c}_{\mathrm{hi}} \overline{\mathrm{y}}_{\mathrm{i} .}\right]^{2}}{\sum_{\mathrm{i}=1}^{\mathrm{I}} \mathrm{c}_{\mathrm{hi}}^{2}}$

considering, $\bar{y}_{i .}=\frac{y_{i .}}{r}=\frac{1}{r} \sum_{j=1}^{r} y_{i j}$ and $y_{i j}=\mu+t_{i}+e_{i j}$, the expression can be written:

$\bar{y}_{i .}=\frac{1}{r} \sum_{j=1}^{r}\left(\mu+t_{i}+e_{i j}\right)=\frac{1}{r}\left(r \mu+r t_{i}+e_{i .}\right) \Rightarrow \bar{y}_{i .}=\mu+t_{i}+\frac{e_{i .}}{r}$ 
Substituting equation (2) into equation (1) the following expression is obtained:

$$
\mathrm{z}_{\mathrm{h}}^{2}=\frac{\left[\sum_{\mathrm{i}=1}^{\mathrm{I}} \mathrm{c}_{\mathrm{hi}}\left(\mu+\mathrm{t}_{\mathrm{i}}+\frac{\mathrm{e}_{\mathrm{i} .}}{\mathrm{r}}\right)\right]^{2}}{\sum_{\mathrm{i}=1}^{\mathrm{I}} \mathrm{c}_{\mathrm{hi}}^{2}},
$$

Considering that $\sum_{\mathrm{i}=1}^{\mathrm{I}} \mathrm{c}_{\mathrm{hi}}=0$, ever $\mathrm{h}=1, \ldots,(\mathrm{I}-1)$, and applying to (3), the obtained form is:

$$
\mathrm{z}_{\mathrm{h}}^{2}=\frac{\left[\sum_{\mathrm{i}=1}^{\mathrm{I}} \mathrm{c}_{\mathrm{hi}}\left(\mathrm{t}_{\mathrm{i}}+\frac{\mathrm{e}_{\mathrm{i.}}}{\mathrm{r}}\right)\right]^{2}}{\sum_{\mathrm{i}=1}^{\mathrm{I}} \mathrm{c}_{\mathrm{hi}}^{2}}
$$

Considering that $\mathrm{E}\left(\mathrm{t}_{\mathrm{i}}\right)=\mathrm{t}_{\mathrm{i}}, \mathrm{E}\left(\mathrm{e}_{\mathrm{ij}}\right)=0$ and $\mathrm{E}\left(\mathrm{e}_{\mathrm{ij}}^{2}\right)=\sigma^{2}$ and also, $\mathrm{E}\left(\mathrm{t}_{\mathrm{i}} \mathrm{e}_{\mathrm{ij}}\right)=0$, thus

$\mathrm{E}\left(\mathrm{z}_{\mathrm{h}}^{2}\right)=\mathrm{E}\left[\frac{\left[\sum_{\mathrm{i}=1}^{\mathrm{I}} \mathrm{c}_{\mathrm{hi}}\left(\mathrm{t}_{\mathrm{i}}+\frac{\mathrm{e}_{\mathrm{i}}}{\mathrm{r}}\right)\right]^{2}}{\sum_{\mathrm{i}=1}^{\mathrm{I}} \mathrm{c}_{\mathrm{hi}}^{2}}\right] \Rightarrow \mathrm{E}\left(\mathrm{z}_{\mathrm{h}}^{2}\right)=\frac{\left(\sum_{\mathrm{i}=1}^{\mathrm{I}} \mathrm{c}_{\mathrm{hi}} \mathrm{t}_{\mathrm{i}}\right)^{2}}{\sum_{\mathrm{i}=1}^{\mathrm{I}} \mathrm{c}_{\mathrm{hi}}^{2}}+\frac{\sum_{\mathrm{i}=1}^{\mathrm{I}} \mathrm{c}_{\mathrm{hi}}^{2} \sigma^{2}}{\mathrm{r} \sum_{\mathrm{i}=1}^{\mathrm{I}} \mathrm{c}_{\mathrm{hi}}^{2}}$

$E\left(z_{h}^{2}\right)=\frac{\left(\sum_{i=1}^{1} c_{h i} t_{i}\right)^{2}}{\sum_{i=1}^{1} c_{h i}^{2}}+\frac{\sigma^{2}}{r} \Rightarrow r E\left(z_{h}^{2}\right)=r Y_{h}^{2}+\sigma^{2}$.

If $\mathrm{Y}_{\mathrm{h}}=0, \mathrm{E}\left(\mathrm{z}_{\mathrm{h}}\right)=0$, and since $\mathrm{z}_{\mathrm{h}}$ follow a normal distribution, and supposing the null hypothesis $\mathrm{H}_{0}$ : $\mathrm{Y}_{\mathrm{h}}=0$, thus

$$
\mathrm{rz} \mathrm{z}_{\mathrm{h}}^{2} \sim \sigma^{2} \chi_{(1)}^{2} .
$$

Now supposing

$\mathrm{z}^{\prime} \mathrm{z}=\hat{\tau}^{\prime} \mathrm{G} \mathrm{G}^{\prime} \hat{\tau}$

and that

$$
\mathrm{G}^{*} \mathrm{G}^{* \prime}=\mathrm{g}_{0} \mathrm{~g}_{0}^{\prime}+\mathrm{GG}^{\prime}=\frac{1}{\sqrt{\mathrm{I}}} \mathrm{E} \mathrm{E}^{\prime} \frac{1}{\sqrt{\mathrm{I}}}+\mathrm{G} \mathrm{G}^{\prime}
$$

where $\mathrm{EE}^{\prime}$ is a matrix of elements 1 , thus

$$
\hat{\tau}^{\prime} G^{*} G^{* \prime} \hat{\tau}=\frac{1}{I} \hat{\tau}^{\prime} E E^{\prime} \hat{\tau}+\hat{\tau}^{\prime} G G^{\prime} \hat{\tau}
$$

and like matrix $\mathrm{G}^{*}$, is also a orthogonal matrix and $E E^{\prime} \hat{\tau}=0$. Due to the restriction relative to $\sum_{i=1}^{I} t_{i}=0$, thus

$$
\hat{\tau}^{\prime} G^{*} G^{*} \hat{\tau}=\hat{\tau}^{\prime} G G^{\prime} \hat{\tau}
$$

Considering that $\mathrm{G}^{*} \mathrm{G}^{*}$ ' $=\mathrm{I}$, due to the orthogonality of matrix $\mathrm{G}^{*}$, which means

$$
\hat{\tau}^{\prime} \hat{\tau}=\hat{\tau}^{\prime} G^{\prime} G^{\prime} \hat{\tau}
$$

The comparison between (5) with (4) evidences that $\mathrm{z}^{\prime} \mathrm{Z}=\hat{\tau}^{\prime} \hat{\tau}$ and consequently,

$$
z^{\prime} z=\hat{\tau}^{\prime} \hat{\tau}=\sum_{i=1}^{I}\left(\bar{y}_{i .}-\bar{y}_{. .}\right)^{2}
$$

The one by one element multiplication of (6) by r, results in:

$$
r\left(z^{\prime} z\right)=r \sum_{i=1}^{I}\left(\bar{y}_{i .}-\bar{y}_{. .}\right)^{2}=S S T
$$

In this way, the sum of squares due to $\mathrm{Y}_{\mathrm{h}}$ is obtained by

$$
\operatorname{SSY}_{\mathrm{h}}=\mathrm{rz} \mathrm{z}_{\mathrm{h}}^{2}=\frac{\mathrm{r}\left(\sum_{\mathrm{i}=1}^{\mathrm{I}} \mathrm{c}_{\mathrm{hi}} \overline{\mathrm{y}}_{\mathrm{i}}\right)^{2}}{\sum_{\mathrm{i}=1}^{\mathrm{I}} \mathrm{c}_{\mathrm{hi}}^{2}}=\frac{\left(\sum_{\mathrm{i}=1}^{\mathrm{I}} \mathrm{c}_{\mathrm{hi}} \mathrm{y}_{\mathrm{i} .}\right)^{2}}{\mathrm{r} \sum_{\mathrm{i}=1}^{\mathrm{I}} \mathrm{c}_{\mathrm{hi}}^{2}} \text {, with one }
$$

degree of freedom, having the following properties:

(i) If $\mathrm{Y}_{\mathrm{h}}=0$, the $\mathrm{SSY}_{\mathrm{h}} \sim \sigma^{2} \chi_{(1)}^{2}$; freedom

(ii) The $\mathrm{SST}=\sum_{\mathrm{h}=1}^{\mathrm{I}-1} \mathrm{SSY}_{\mathrm{h}}$, with (I-1) degrees of

Hinkelmann \& Kempthorne (1994) considered that,

$$
\mathrm{SST}=\sum_{\mathrm{h}=1}^{\mathrm{I}-1} \mathrm{SQY}_{\mathrm{h}} \text {, with (I-1) degrees of freedom in }
$$
order to demonstrate that

$$
\mathrm{z}=\left(\begin{array}{l}
\mathrm{g}_{0}^{\prime} \\
\mathrm{g}_{1}^{\prime} \\
\vdots \\
\mathrm{g}_{\mathrm{I}-1}^{\prime}
\end{array}\right) \overline{\mathrm{y}}=\mathrm{G}^{\prime} \overline{\mathrm{y}}
$$

where $G^{\prime}$ is an orthogonal matrix, and thus

$z^{\prime} z=\bar{y}^{\prime} G G^{\prime} \bar{y}=\bar{y}^{\prime} I \bar{y}=\bar{y}^{\prime} \bar{y}=\sum_{i=1}^{I} \bar{y}_{i}^{2}$

These authors observed also that

$\mathrm{z}^{\prime} \mathrm{z}=\sum_{\mathrm{h}=0}^{\mathrm{I}-1} \mathrm{z}_{\mathrm{h}}^{2}=\sum_{\mathrm{h}=0}^{\mathrm{I}-1}\left[\mathrm{~g}_{\mathrm{h}}^{\prime} \overline{\mathrm{y}}\right]^{2}=\left[\mathrm{g}_{0}^{\prime} \overline{\mathrm{y}}\right]^{2}+\sum_{\mathrm{h}=1}^{\mathrm{I}-1}\left[\mathrm{~g}_{\mathrm{h}}^{\prime} \overline{\mathrm{y}}\right]^{2}=\frac{1}{\mathrm{I}}\left[\sum_{\mathrm{i}=1}^{\mathrm{I}} \overline{\mathrm{y}}_{\mathrm{i}}\right]^{2}+\sum_{\mathrm{h}=1}^{\mathrm{I}-1}\left[\mathrm{~g}_{\mathrm{h}}^{\prime} \overline{\mathrm{y}}\right]^{2}$

and thus, 
$\frac{1}{\mathrm{I}}\left[\sum_{\mathrm{i}=1}^{\mathrm{I}} \bar{y}_{\mathrm{i} .}\right]^{2}=\frac{1}{\mathrm{I}}\left[\sum_{\mathrm{i}=1}^{\mathrm{I}} \sum_{\mathrm{j}=1}^{\mathrm{r}} \frac{\mathrm{y}_{\mathrm{ij}}}{\mathrm{r}}\right]^{2}=\frac{1}{\mathrm{I}}\left[\frac{\mathrm{y}_{. .}}{\mathrm{r}}\right]^{2}=\frac{1}{\mathrm{I}}\left[\mathrm{I} \frac{\mathrm{y}_{. .}}{\mathrm{Ir}}\right]^{2}=\mathrm{I} \bar{y}_{. .}^{2}$

resulting

$$
\mathrm{z}^{\prime} \mathrm{z}=\mathrm{I} \bar{y}_{. .}^{2}+\sum_{\mathrm{h}=1}^{\mathrm{I}-1}\left[\mathrm{~g}_{\mathrm{h}}^{\prime} \overline{\mathrm{y}}\right]^{2}
$$

Using equation (7) in (8), results that

$$
\begin{aligned}
& \sum_{i=1}^{I} \bar{y}_{i .}^{2}=I \bar{y}_{. .}^{2}+\sum_{h=1}^{I-1}\left[g_{h}^{\prime} \bar{y}\right]^{2} \\
& \sum_{i=1}^{I} \bar{y}_{i .}^{2}-I \bar{y}_{. .}^{2}=\sum_{h=1}^{I-1}\left[g_{h}^{\prime} \bar{y}\right]^{2} \\
& \sum_{i=1}^{I}\left(\bar{y}_{i .}-\bar{y}_{. .}\right)^{2}=\sum_{h=1}^{I-1}\left[g_{h}^{\prime} \bar{y}\right]^{2}
\end{aligned}
$$

The one by one element multiplication of (9) by r, results in:

$$
\mathrm{r} \sum_{\mathrm{i}=1}^{\mathrm{I}}\left(\overline{\mathrm{y}}_{\mathrm{i} .}-\overline{\mathrm{y}}_{. .}\right)^{2}=\mathrm{r} \sum_{\mathrm{h}=1}^{\mathrm{I}-1}\left[\mathrm{~g}_{\mathrm{h}}^{\prime} \overline{\mathrm{y}}\right]^{2}=\mathrm{SST}
$$

with (I-1) degrees of freedom.

This result can be included into the analysis of variance table, originating a more detailed table, as the example in table 1.

In order to test the hypothesis $\mathrm{H}_{0}: \mathrm{Y}_{\mathrm{h}}=0$, which may also be written as $\mathrm{H}_{0}: \mathrm{c}^{\prime} \tau=0$, test $\mathrm{F}$ is applied, so that

$$
\mathrm{F}=\frac{\mathrm{SSY}_{\mathrm{h}}}{\mathrm{MSR}} \sim \mathrm{F}_{(1, \mathrm{v})}
$$

\begin{tabular}{|c|c|c|c|}
\hline $\begin{array}{l}\text { Sources of } \\
\text { Variation }\end{array}$ & DF & SS & E (MS) \\
\hline Treatment & $(\mathrm{I}-1)$ & SST & $\sigma^{2}+\frac{r}{I-1} \sum_{i=1}^{I} t_{i}^{2}$ \\
\hline $\mathrm{Y}_{1}$ & 1 & $\mathrm{SSY}_{1}$ & $\sigma^{2}+\mathrm{rY}_{1}^{2}$ or $\sigma^{2}+\mathrm{r}\left(\mathrm{c}_{1}^{\prime} \tau\right)^{2}$ \\
\hline $\mathrm{Y}_{2}$ & 1 & $\mathrm{SS} \mathrm{Y}_{2}$ & $\sigma^{2}+r Y_{2}^{2}$ or $\sigma^{2}+r\left(c_{2}^{\prime} \tau\right)^{2}$ \\
\hline$\vdots$ & $\vdots$ & $\vdots$ & $\vdots$ \\
\hline$Y_{I-1}$ & 1 & SS $Y_{\mathrm{I}-1}$ & $\sigma^{2}+r Y_{I-1}^{2}$ or $\sigma^{2}+r\left(c_{I-1}^{\prime} \tau\right)^{2}$ \\
\hline Residual & $\mathrm{I}(\mathrm{r}-1)$ & SSR & $\sigma^{2}$ \\
\hline
\end{tabular}

where MSR is the mean square residual and v corresponds to the degrees of freedom related to the $\mathrm{F}$ denominator, that is, in this case, $\mathrm{v}=\mathrm{I}(\mathrm{r}-1)$.

Table 1 - Analysis of variance with decomposion in orthogonal contrasts.
Alternatively, a confidence interval for $\mathrm{Y}_{\mathrm{h}}$, with (1- $\alpha) 100 \%$, is given:

$$
\hat{\mathrm{Y}}_{\mathrm{h}} \pm \mathrm{t}_{\left(\frac{\alpha}{2}, v\right)} \sqrt{\hat{\mathrm{V}}\left(\hat{\mathrm{Y}}_{\mathrm{h}}\right)}
$$

where $\mathrm{v}$ refers to the degrees of freedom related to $\hat{\mathrm{V}}\left(\hat{\mathrm{Y}}_{\mathrm{h}}\right)$, so that

$\hat{\mathrm{V}}\left(\hat{\mathrm{Y}}_{\mathrm{h}}\right)=\sum_{\mathrm{i}=1}^{\mathrm{I}} \mathrm{c}_{\mathrm{hi}}^{2} \hat{\mathrm{V}}\left(\overline{\mathrm{y}}_{\mathrm{i} .}\right)=\sum_{\mathrm{i}=1}^{\mathrm{I}} \mathrm{c}_{\mathrm{hi}}^{2} \frac{\hat{\sigma}^{2}}{\mathrm{r}}=\sum_{\mathrm{i}=1}^{\mathrm{I}} \mathrm{c}_{\mathrm{hi}}^{2} \frac{\mathrm{MSR}}{\mathrm{r}}$

and where $\hat{\sigma}^{2}$ refers to SSR, with I(r-1) degrees of freedom, hence $\mathrm{v}=\mathrm{I}(\mathrm{r}-1)$.

According Scheffé (1959), the hypothesis $\mathrm{H}_{0}: \mathrm{t}_{1}=\mathrm{t}_{2}=\ldots=\mathrm{t}_{\mathrm{I}}=0$, initially tested by the test $\mathrm{F}$, described in table 1 , is equivalent to the hypothesis

$$
\mathrm{H}_{0}: \mathrm{Y}_{1}=\mathrm{Y}_{2}=\cdots=\mathrm{Y}_{\mathrm{I}-1}=0,
$$

(an alternative hypothesis $\mathrm{H}_{\mathrm{a}}$ which consists of at least one contrast $Y_{h}$ diferent from zero), and where $\left\{Y_{1}, Y_{2}\right.$, $\left.\cdots, \mathrm{Y}_{\mathrm{I}-1}\right\}$ is a group of predictable independent linear functions. given by

Supposing $\hat{\mathrm{Y}}_{\mathrm{h}}$ is an unbiased estimator of $\mathrm{Y}_{\mathrm{h}}$, $\hat{\mathrm{Y}}_{\mathrm{h}}=\sum_{\mathrm{i}=1}^{\mathrm{I}} \mathrm{c}_{\mathrm{hi}} \mathrm{t}_{\mathrm{i}}=\sum_{\mathrm{i}=1}^{\mathrm{I}} \mathrm{c}_{\mathrm{hi}} \overline{\mathrm{y}}_{\mathrm{i} .}$, where $\overline{\mathrm{y}}_{\mathrm{i} .}=\frac{\sum_{\mathrm{j}=1}^{\mathrm{r}} \mathrm{y}_{\mathrm{ij}}}{\mathrm{r}} \sim \mathrm{N}\left(\mu_{\mathrm{i}}\right.$,
$\left.\frac{\sigma^{2}}{\mathrm{r}}\right)$ and independents and $\mathrm{V}\left(\hat{\mathrm{Y}}_{\mathrm{h}}\right)=\sum_{\mathrm{i}=1}^{\mathrm{I}} \mathrm{c}_{\mathrm{hi}}^{2} \mathrm{~V}\left(\overline{\mathrm{y}}_{\mathrm{i}}\right)=\sum_{\mathrm{i}=1}^{\mathrm{I}} \frac{\mathrm{c}_{\mathrm{hi}}^{2}}{\mathrm{r}} \sigma^{2} \Rightarrow \hat{\mathrm{V}}\left(\hat{\mathrm{Y}}_{\mathrm{h}}\right)=\sum_{\mathrm{i}=1}^{\mathrm{I}} \frac{\mathrm{c}_{\mathrm{hi}}^{2}}{\mathrm{r}} \hat{\sigma}^{2}=\sum_{\mathrm{i}=1}^{\mathrm{I}} \frac{\mathrm{c}_{\mathrm{hi}}^{2}}{\mathrm{r}} \mathrm{MSR}$ the author demonstrates that the probability of all contrast values to fulfill simultaneously the unequal expression written below, is $(1-\boldsymbol{\alpha})$ :

$\hat{\mathrm{Y}}_{\mathrm{h}}-\mathrm{S} \hat{\sigma}_{\hat{\mathrm{Y}}} \leq \mathrm{Y}_{\mathrm{h}} \leq \hat{\mathrm{Y}}_{\mathrm{h}}+\mathrm{S} \hat{\sigma}_{\hat{\mathrm{Y}}}$

or else,

$$
\left|\hat{\mathrm{Y}}_{\mathrm{h}}\right| \geq \mathrm{S} \hat{\sigma}_{\hat{\mathrm{Y}}}
$$

where the constant $\mathrm{S}$ is obtained by the following expression

$$
\mathrm{S}=\sqrt{(\mathrm{I}-1) \mathrm{F}_{(\alpha, \mathrm{I}-1, \mathrm{I}(\mathrm{r}-1))}} \text { and } \hat{\sigma}_{\hat{\mathrm{Y}}}=\sqrt{\hat{\operatorname{Var}}\left(\hat{\mathrm{Y}}_{\mathrm{h}}\right)} \text {. }
$$

The method described is the Scheffé method applied to multiple comparisons using intervals for the contrasts. This method is related to the $\mathrm{F}$ test, when testing the hypothesis $\mathrm{H}_{0}: \mathrm{t}_{1}=\mathrm{t}_{2}=\ldots=\mathrm{t}_{\mathrm{I}}=0$, as follows: if $\hat{\mathrm{Y}}_{\mathrm{h}}$ is considered significantly different from zero, which implies that $Y_{h}=0$ is excluded of the interval (10). Now, if $0 \hat{Y}_{h}$ 
is not considered significantly different from zero, this implies that $Y_{h}=0$ is included in the interval (10). Thus, when $\mathrm{H}_{0}$ is rejected by $\mathrm{F}$ test, the author infers that at least one contrast should be significantly different from zero. In other words, if (and only if) under the significance level a it is concluded by the F test that the contrasts are not all nulls, then the Scheffé method will show contrast estimates that are significantly different from zero.

The level of significance $\alpha$ is the probability of the global type I error or experimentwise, that is, the probability of at least one contrast be significantly different from zero, from a group of (I-1) contrasts, which means:

$$
\alpha=1-\left(1-\alpha^{\prime}\right)^{(\mathrm{I}-1)}
$$

where $\alpha^{\prime}$ is the probability of type I error for a particular contrast (or comparisonwise) applied when the null hypothesis is rejected $\mathrm{H}_{0}: \mathrm{Y}_{\mathrm{h}}=0$, for $\mathrm{h}=1, \ldots,(\mathrm{I}-1)$.

According to Kuehl (1994), the formula

$$
\alpha^{\prime}=1-(1-\alpha)^{\frac{1}{\mathrm{I}-1}}
$$

expresses the probability of type I error for a particular contrast (comparisonwise) as a function of the global type I error (experimentwise). For ordinary calculations a' is considered closely $\alpha /(\mathrm{I}-1)$.

However, it may occur that none of these contrasts significantly different from zero are of practical interest. An example of a non-practical contrast is the normalized maximal contrast $\hat{\mathrm{Y}}_{\max }$ estimate.

\section{Definition and estimation of $\hat{\mathrm{Y}}_{\max }$}

Scheffé (1959) demonstrated that $\mathrm{SST}=\mathrm{SSY}_{\max }$ $=\hat{Y}_{\max }^{2}$, where $\hat{\mathrm{Y}}_{\max }$ is the normalized contrast estimate for the effect $\left\{\mathrm{t}_{\mathrm{i}}\right\}$ maximal, defined as: suppose $\mathrm{L}$ is the sampling space for all the contrasts in $\left\{\mathrm{t}_{\mathrm{i}}\right\}$, and $\mathrm{L}$ " is the group of all normalized contrasts in $\mathrm{L}$, that is, the group of all $\mathrm{Y}$ in $\mathrm{L}$, so that the $\operatorname{Var}(\hat{\mathrm{Y}})=\mathrm{C} \sigma^{2}$, and that $\mathrm{C}=1$. Thus, $\hat{\mathrm{Y}}_{\max }$ is maximal $\hat{\mathrm{Y}}$ with $\mathrm{Y}$ in $\mathrm{L}$ ". If

$\hat{\mathrm{Y}}=\sum_{\mathrm{i}=1}^{\mathrm{I}} \mathrm{c}_{\mathrm{i}} \overline{\mathrm{y}}_{\mathrm{i} .}=\sum_{\mathrm{i}=1}^{\mathrm{I}} \mathrm{c}_{\mathrm{i}}\left(\sum_{\mathrm{j}=1}^{\mathrm{r}} \mathrm{w}_{\mathrm{j}} \mathrm{y}_{\mathrm{ij}}\right)$

where $\mathrm{w}_{\mathrm{j}}=1 / \mathrm{r}$, so that $\mathrm{w}_{\mathrm{j}} \geq 0$ and $\sum_{\mathrm{j}=1}^{\mathrm{r}} \mathrm{w}_{\mathrm{j}}=1$, and
thus

$$
\hat{\mathrm{Y}}=\sum_{\mathrm{i}=1}^{\mathrm{I}} \sum_{\mathrm{j}=1}^{\mathrm{r}} \mathrm{c}_{\mathrm{i}} \mathrm{w}_{\mathrm{j}} \mathrm{y}_{\mathrm{ij}}
$$

with $\operatorname{Var}(\hat{\mathrm{Y}})=\sum_{\mathrm{i}=1}^{\mathrm{I}} \sum_{\mathrm{j}=1}^{\mathrm{r}} \mathrm{c}_{\mathrm{i}}^{2} \mathrm{w}_{\mathrm{j}}^{2} \frac{\sigma^{2}}{\mathrm{~K}_{\mathrm{ij}}}$, considering in this case $\mathrm{K}_{\mathrm{ij}}=1$, for all $\mathrm{i}=1, \ldots, \mathrm{I}$ and $\mathrm{j}=1, \ldots, \mathrm{r}$, which represents the number of times in which $i$ and $j$ appear together, that is, for the present case in study the consid- ered structure is a treatment factor with I levels and completely random $r$ replications, each level $i$ of the considered treatment factor occurring only once with the $\mathrm{j}$ replication. Supposing the above considerations the following expression may be written:

$$
\operatorname{Var}(\hat{\mathrm{Y}})=\sum_{\mathrm{i}=1}^{\mathrm{I}} \sum_{\mathrm{j}=1}^{\mathrm{r}} \mathrm{c}_{\mathrm{i}}^{2} \mathrm{w}_{\mathrm{j}}^{2} \sigma^{2},
$$

The restrictions for $\hat{\mathrm{Y}}$ being in L", are the following:

$$
\sum_{i=1}^{I} c_{i}=0 \text { and } \sum_{i=1}^{I} \sum_{j=1}^{r} c_{i}^{2} w_{j}^{2}=1
$$

Hence, to maximize $\hat{\mathrm{Y}}=\sum_{\mathrm{i}=1}^{\mathrm{I}} \mathrm{c}_{\mathrm{i}} \overline{\mathrm{y}}_{\mathrm{i} \text {. }}$, variations on $\left\{c_{i}\right\}$ are observed while $\left\{\bar{y}_{i}\right\}$ are remained fixed and thus, it is convenient to consider that

$$
\sum_{i=1}^{I} \sum_{j=1}^{r} c_{i}^{2} w_{j}^{2}=1 \Rightarrow \sum_{i=1}^{I} c_{i}^{2}\left[\sum_{j=1}^{r} w_{j}^{2}\right]=1 \Rightarrow \sum_{i=1}^{I} c_{i}^{2}=\frac{1}{\sum_{j=1}^{r} w_{j}^{2}}=\frac{1}{\sum_{j=1}^{r} w_{j}^{2}}=\frac{1}{\sum_{j=1}^{r} \frac{1}{r^{2}}}=r,
$$

and thereafter, this leads to $\sum_{i=1}^{I} \frac{c_{i}^{2}}{r}=1$.

In order to maximize $\hat{Y}$, the following conditions are imposed:

$$
\sum_{i=1}^{\mathrm{I}} \mathrm{c}_{\mathrm{i}}=0 \text { and } \sum_{\mathrm{i}=1}^{\mathrm{I}} \frac{\mathrm{c}_{\mathrm{i}}^{2}}{\mathrm{r}}=1 \Rightarrow \sum_{\mathrm{i}=1}^{\mathrm{I}} \frac{\mathrm{c}_{\mathrm{i}}^{2}}{\mathrm{r}}-1=0 .
$$
we have:

Applying the technique Lagrange's multipliers,

$\mathrm{L}\left(\mathrm{c}, \lambda_{1}, \lambda_{2}\right)=\mathrm{f}(\mathrm{c})+\lambda_{1} \mathrm{~g}(\mathrm{c})+\lambda_{2} \mathrm{~h}(\mathrm{c})$

$$
=\sum_{\mathrm{i}=1}^{\mathrm{I}} \mathrm{c}_{\mathrm{i}} \overline{\mathrm{y}}_{\mathrm{i} .}+\lambda_{1} \sum_{\mathrm{i}=1}^{\mathrm{I}} \mathrm{c}_{\mathrm{i}}+\lambda_{2}\left[\sum_{\mathrm{i}=1}^{\mathrm{I}} \frac{\mathrm{c}_{\mathrm{i}}^{2}}{\mathrm{r}}-1\right]
$$

calculating $\frac{\partial \mathrm{L}}{\partial \mathrm{c}_{\mathrm{i}}}=\overline{\mathrm{y}}_{\mathrm{i} .}+\lambda_{1}+2 \lambda_{2} \frac{\mathrm{c}_{\mathrm{i}}}{\mathrm{r}}$, and considering $\frac{\partial \mathrm{L}}{\partial \mathrm{c}_{\mathrm{i}}}=0$, for all $\mathrm{i}$, leads to the form

$$
\bar{y}_{\text {i. }}+\lambda_{1}+2 \lambda_{2} \frac{\mathrm{c}_{\mathrm{i}}}{\mathrm{r}}=0
$$

Isolating the $c_{i}$ element we obtain:

$2 \lambda_{2} \frac{c_{i}}{r}=-\left(\bar{y}_{i .}+\lambda_{1}\right) \Rightarrow c_{i}=-\frac{r\left(\bar{y}_{i .}+\lambda_{1}\right)}{2 \lambda_{2}}$.

Adding (11) in $\sum_{\mathrm{i}=1}^{\mathrm{I}} \mathrm{c}_{\mathrm{i}}=0$, thus 
$\sum_{i=1}^{I} c_{i}=-\sum_{i=1}^{I} \frac{r\left(\bar{y}_{i .}+\lambda_{1}\right)}{2 \lambda_{2}}=0$

resulting

$\sum_{i=1}^{I} r\left(\bar{y}_{i .}+\lambda_{1}\right)=0 \Rightarrow \lambda_{1}=-\frac{\sum_{i=1}^{I} r \bar{y}_{i .}}{\sum_{i=1}^{I} r} \Rightarrow \lambda_{1}=-\frac{\sum_{i=1}^{I} r \frac{y_{i .}}{I r}}{\operatorname{Ir}}=-\frac{y_{. .}}{I r} \Rightarrow \lambda_{1}=-\bar{y}_{. .}$

Hence, placing (12) in (11), leads to

$c_{i}=-\frac{r\left(\bar{y}_{i .}-\bar{y}_{. .}\right)}{2 \lambda_{2}}$,

and placing (13) in $\sum_{i=1}^{\mathrm{I}} \frac{\mathrm{c}_{\mathrm{i}}^{2}}{\mathrm{r}}=1$, leads to

$\sum_{i=1}^{I}\left[-\frac{r\left(\bar{y}_{i .}-\bar{y}_{.} .\right)}{2 \lambda_{2}}\right]^{2} \frac{1}{r}=1 \Rightarrow \sum_{i=1}^{I} \frac{r\left(\bar{y}_{i .}-\bar{y}_{. .}\right)^{2}}{4 \lambda_{2}^{2}}=1 \Rightarrow 4 \lambda_{2}^{2}=r \sum_{i=1}^{I}\left(\bar{y}_{i .}-\bar{y}_{. .}\right)^{2}$ formula

Finally, placing the result obtained in (13) in the

$$
\begin{aligned}
\hat{\mathrm{Y}}_{\max } & =\left[\sum_{\mathrm{i}=1}^{\mathrm{I}} \mathrm{c}_{\mathrm{i}} \overline{\mathrm{y}}_{\mathrm{i} .}\right]^{2} \\
& =\left[-\sum_{\mathrm{i}=1}^{\mathrm{I}} \frac{\mathrm{r}\left(\overline{\mathrm{y}}_{\mathrm{i} .}-\overline{\mathrm{y}}_{. .}\right)}{2 \lambda_{2}} \overline{\mathrm{y}}_{\mathrm{i} .}\right]^{2} \\
& =\frac{\left[\mathrm{r} \sum_{\mathrm{i}=1}^{\mathrm{I}}\left(\overline{\mathrm{y}}_{\mathrm{i} .}-\overline{\mathrm{y}}_{. .}\right)^{2}\right]^{2}}{4 \lambda_{2}^{2}}
\end{aligned}
$$

substituting into (15) the result of (14),

$$
\begin{aligned}
& 4 \lambda_{2}^{2}=\mathrm{r} \sum_{\mathrm{i}=1}^{\mathrm{I}}\left(\overline{\mathrm{y}}_{\mathrm{i} .}-\overline{\mathrm{y}}_{. .}\right)^{2}, \\
& \hat{\mathrm{Y}}_{\max }^{2}=\mathrm{r} \sum_{\mathrm{i}=1}^{I}\left(\overline{\mathrm{y}}_{\mathrm{i} .}-\overline{\mathrm{y}}_{. .}\right)^{2}=\mathrm{SST} .
\end{aligned}
$$

Thus, it is concluded that $\hat{\mathrm{Y}}_{\max }^{2}=\mathrm{SQY}_{\max }=\mathrm{SST}$.

If the interest is to test the null hypothesis $\mathrm{H}_{0}: \mathrm{Y}_{\max }=0$, the rejection area for this test is given by

$$
\left.\mathrm{F}=\frac{\mathrm{SSY}_{\max }}{\mathrm{MSR}}\right\rangle(\mathrm{I}-1) \mathrm{F}_{(\alpha, \mathrm{I}-1, \mathrm{I}(\mathrm{r}-1))},
$$

or by

$\mathrm{F}=\frac{\mathrm{SSY}_{\max } /(\mathrm{I}-1)}{\mathrm{MSR}}=\frac{\mathrm{MST}}{\mathrm{MSR}}>\mathrm{F}_{(\alpha, \mathrm{I}-1, \mathrm{I}(\mathrm{r}-1))}$

where $\alpha$ is the significance level that gives the quantity of the F distribution with (I-1) and I(r-1) degrees of freedom.
It is noticed that the way the test was applied to check the null hypothesis $\mathrm{H}_{0}: \mathrm{Y}_{\max }=0$ is identical to the test applied to verify the hypothesis of no variation due to treatments. If the tested hypothesis in terms of comparisons is not rejected, the resulted implication is in the correspondent comparison in populational terms that it is not significantly different from zero. Then, if the null hypothesis, $\mathrm{H}_{0}: \mathrm{Y}_{\max }=0$, is not rejected, that is, if $\mathrm{Y}_{\max }$ is not significantly different from zero, then no other comparison to be tested will be significantly different from zero, when the Scheffé method is used. If the null hypothesis $\mathrm{H}_{0}: \mathrm{Y}_{\max }=0$ is rejected, this impplies that the correspondent comparison is significantly different from zero. For the group of tests used in the considered comparisons, the Scheffé method is referred to the a level of significance, which means that the a level of significance is the probability of the global type I error (or experimentwise), correspondent to the totality of tests used.

\section{Definitions and Concepts for mean contrasts with un- equal number of replications}

In the case of treatments with unequal number of replications, that is, for $\mathrm{j}=1, \ldots, \mathrm{r}_{\mathrm{i}}$, (Steel \& Torrie, 1981, cited in Nogueira, 1997), consider that for a given contrast

$$
\hat{\mathrm{Y}}_{\mathrm{h}}=\sum_{\mathrm{i}=1}^{\mathrm{I}} \mathrm{c}_{\mathrm{hi}} \mathrm{y}_{\mathrm{i} .}=\sum_{\mathrm{i}=1}^{\mathrm{I}} \mathrm{r}_{\mathrm{i}} \mathrm{c}_{\mathrm{hi}} \overline{\mathrm{y}}_{\mathrm{i} .},
$$

where $\bar{y}_{i .}=\frac{\sum_{j=1}^{r_{i}} y_{i j}}{r_{i}}=\frac{y_{i .}}{r_{i}} \sim N\left(\mu_{i}, \frac{\sigma^{2}}{r_{i}}\right)$ and independent of each other, and, $r_{i}$ is the number of replications of treatment $\mathrm{i} ; \mathrm{c}_{\mathrm{hi}}$ is the coefficient to be attributed to $\overline{\mathrm{y}}_{\mathrm{i}}$; and $\bar{y}_{i}$ is the mean estimate of treatment $i$, so that

$$
\sum_{i=1}^{I} r_{i} c_{h i}=0 \text {. }
$$

Moreover, $\quad \mathrm{E}\left(\hat{\mathrm{Y}}_{\mathrm{h}}\right)=\sum_{\mathrm{i}=1}^{\mathrm{I}} \mathrm{r}_{\mathrm{i}} \mathrm{c}_{\mathrm{hi}} \mu_{\mathrm{i}}=\mathrm{Y}_{\mathrm{h}} \quad$ and $\operatorname{Var}\left(\hat{\mathrm{Y}}_{\mathrm{h}}\right)=\sum_{\mathrm{i}=1}^{\mathrm{I}} \mathrm{r}_{\mathrm{i}} \mathrm{c}_{\mathrm{hi}}^{2} \sigma^{2}$. Thus, $\hat{\mathrm{Y}}_{\mathrm{h}}$ is defined as the contrast between treatment means obtained from data with unequal number of replications.

Supposing that $\mu_{\mathrm{i}}=\mu+\mathrm{t}_{\mathrm{i}}$, where $\mu$ is a constant and $\mathrm{T}_{\mathrm{i}}$ is the effect of treatment $i$, the following expression is written:

$$
Y_{h}=\sum_{i=1}^{I} r_{i} c_{h i}\left(\mu+t_{i}\right)=\mu \sum_{i=1}^{I} r_{i} c_{h i}+\sum_{i=1}^{I} r_{i} c_{h i} t_{i}=\sum_{i=1}^{I} r_{i} c_{h i} t_{i}
$$


Two contrasts $Y_{h}=\sum_{i=1}^{I} r_{i} c_{h i} \mu_{i}$ and
$\sum_{i=1}^{I} r_{i} c_{h^{\prime} i} \mu_{i}$ where $h \neq h$, and $h=1, \ldots,(I-1)$, are orthogonal when $\left\langle\mathrm{r}_{\mathrm{i}} \mathrm{c}_{\mathrm{hi}}, \mathrm{r}_{\mathrm{i}} \mathrm{c}_{\mathrm{h}^{\prime} \mathrm{i}}\right\rangle=0$, that is,

$$
\sum_{\mathrm{i}=1}^{\mathrm{I}} \mathrm{r}_{\mathrm{i}} \mathrm{c}_{\mathrm{hi}} \mathrm{c}_{\mathrm{h}^{\prime} \mathrm{i}}=0 \text {. }
$$

Hence, the null hypothesis means of

$$
\mathrm{H}_{0}: \mathrm{Y}_{\mathrm{h}}=\sum_{\mathrm{i}=1}^{\mathrm{I}} \mathrm{r}_{\mathrm{i}} \mathrm{c}_{\mathrm{hi}} \mu_{\mathrm{i}}=0 \text { can be tested by }
$$

$$
\mathrm{F}_{\left(\mathrm{Y}_{\mathrm{h}}\right)}=\frac{\mathrm{SSY}_{\mathrm{h}}}{\mathrm{MSR}} \sim \mathrm{F}_{(\alpha, 1, \mathrm{v})}
$$

where $\operatorname{SSY}_{\mathrm{h}}=\frac{\hat{\mathrm{Y}}_{\mathrm{h}}^{2}}{\sum_{\mathrm{i}=1}^{\mathrm{I}} \mathrm{r}_{\mathrm{i}} \mathrm{c}_{\mathrm{hi}}^{2}}$ and $\mathrm{v}=\sum_{\mathrm{i}=1}^{\mathrm{I}}\left(\mathrm{r}_{\mathrm{i}}-1\right)=\mathrm{n}-\mathrm{I}$, where $\mathrm{n}$ is the total number of observations, that is, $\mathrm{n}=\sum_{\mathrm{i}=1}^{\mathrm{I}} \mathrm{r}_{\mathrm{i}}$.

Kirk (1968), for average data from unequal number of replications, considers that

$$
\hat{\mathrm{Y}}_{\mathrm{h}}=\sum_{\mathrm{i}=1}^{\mathrm{I}} \mathrm{c}_{\mathrm{hi}} \overline{\mathrm{y}}_{\mathrm{i} .},
$$
so that $\sum_{\mathrm{i}=1}^{\mathrm{I}} \mathrm{c}_{\mathrm{hi}}=0$ and the orthogonal condition is as fol-
lows:

$$
\sum_{i=1}^{I} \frac{c_{h i} c_{h^{\prime} i}}{r_{i}}=0
$$

Thus, the null hypothesis

$$
\mathrm{H}_{0}: \mathrm{Y}_{\mathrm{h}}=\sum_{\mathrm{i}=1}^{\mathrm{I}} \mathrm{c}_{\mathrm{hi}} \mu_{\mathrm{i}}=0
$$

can be tested by means of

$$
\mathrm{F}_{\left(\mathrm{Y}_{\mathrm{h}}\right)}=\frac{\mathrm{SSY}_{\mathrm{h}}}{\mathrm{MSR}} \sim \mathrm{F}_{(\alpha, 1, \mathrm{v})}
$$

where $S S Y_{h}=\frac{\hat{Y}_{h}^{2}}{\sum_{\mathrm{i}=1}^{\mathrm{I}} \frac{\mathrm{c}_{\mathrm{hi}}^{2}}{\mathrm{r}_{\mathrm{i}}}}$ and $\mathrm{v}=\sum_{\mathrm{i}=1}^{\mathrm{I}}\left(\mathrm{r}_{\mathrm{i}}-1\right)=\mathrm{n}-\mathrm{I}$.

Winer (1971) and Kirk (1968) showed that the sum of squares due to $Y_{h}$, for the case of unequal number of replications, is given by the following expression:

$$
\operatorname{SSY}_{h}=\frac{\hat{Y}_{h}^{2}}{\sum_{i=1}^{I} \frac{c_{h i}^{2}}{r_{i}}} \text { when } c_{i}=\frac{r_{i}\left(\bar{y}_{i .}-\bar{y}_{. .}\right)}{\sqrt{\sum_{i=1}^{I} r_{i}\left(\bar{y}_{i .}-\bar{y}_{. .}\right)^{2}}}
$$

and, suggested that the $\mathrm{SSY}_{\text {max }}$ is obtained when and this leads

$$
\mathrm{SSY}_{\max }=\mathrm{Y}_{\max }^{2}=\sum_{\mathrm{i}=1}^{\mathrm{I}} \mathrm{r}_{\mathrm{i}}\left(\overline{\mathrm{y}}_{\mathrm{i} .}-\overline{\mathrm{y}}_{. .}\right)^{2}=\mathrm{SST}
$$

to according to Scheffé (1959).

\section{REFERENCES}

CORRENTE, J.E.; NOGUEIRA, M.C.S.; COSTA, B.M. Contrastes ortogonais na análise do controle de volatilização de amônia em compostagem. Sci. Agric. (Piracicaba Braz.) v.58, p.407-412, 2001.

HINKELMANN, K.; KEMPTHORNE, O. Design and analysis of experiments. New York: Wiley-Interscience, 1994. v.1, 495p.

KUEHL, R.O. Statistical principles of research design and analysis. Belmont: Duxbury Press. 1994.681p.

MEAD, R. The design of experiment: Statistical principles for practical application. Cambridge: Cambridge University Press, 1988. 618p.

NOGUEIRA, M.C.S. Estatística experimental aplicada à experimentação agronômica. Piracicaba: ESALQ, DME, 1997. 250p.

NOGUEIRA, M.C.S.; CORRENTE, J.E. Decomposição da interação tripla significativa utilizando o comando contrast do PROC GLM do SAS, aplicado ao modelo de classificação tripla para dados balanceados. Bragantia. v.59, p.109-115, 2000.

SCHEFFÉ, H. Analysis of variance. London: John Wiley \& Sons, 1959. $467 \mathrm{p}$.

STEEL, R.G.D.; TORRIE, J.H. Principles and procedures of statistics: A biometrical approach. 2.ed. New York: McGraw-Hill International Book Company, 1981. 625p.

WINER, B.J. Statistical principles in experimental design.2.ed. New York: MacGraw-Hill Book Company, 1971. 897p.

Received October 11,2002

Accepted October 29, 2003 